\title{
Culture-Integrated Teaching for the Enhancement of EFL Learner Tolerance
}

\author{
Mohammad Abdollahi-Guilani ${ }^{1}$, Mohamad Subakir Mohd Yasin ${ }^{1}$, Tan Kim Hua ${ }^{1}$ \& Khadijeh Aghaei $^{1}$ \\ ${ }^{1}$ School of Language Studies and Linguistics, Faculty of Social Science and Humanities, Universiti Kebangsaan \\ Malaysia (UKM), Malaysia \\ Correspondence: Mohammad Abdollahi-Guilani (PhD), School of Language Studies and Linguistics, Faculty of \\ Social Science and Humanities, Universiti Kebangsaan Malaysia (UKM), Malaysia. Tel: 60-16-305-4193. \\ E-mail: abdollahi20@gmail.com
}

Received: December 23, 2011 Accepted: January 20, $2012 \quad$ Published: May 1, 2012

doi:10.5539/ass.v8n6p115

URL: http://dx.doi.org/10.5539/ass.v8n6p115

\begin{abstract}
This paper discusses the significance of learning and teaching culture as an inseparable part of language and invites language teachers to integrate cultural points into the syllabus of language programs. A learner may have a good command of grammar and lexicon, but have difficulty in comprehending the message. Understanding why communication is possible for certain readers but not for others can partly lie in the cultural shades of the words and events. For some nationalities, gestures, names, numbers, and colors are suggestive of ill manners, while in others, they are welcome. This study justifies the importance of including culture in the language teaching programs because familiarity with the cultural features of the target language people can help the learners see the world with open eyes and modify their attitude toward other cultures. This can generally enhance their tolerance not only as a language learner but also as a human being.
\end{abstract}

Keywords: awareness, cultural tolerance, gesture, language learning, social behavior, vocabulary, EFL learners

\section{Introduction}

Language is developed differently in people's minds and so it is manifested in different shapes. This lies in culture, geography, climate, and even the physiology of their bodies. Based on individuals' experiences, language is interpreted differently and represented accordingly. Learning a new language means a lot more than the manipulation of syntax and lexicon.

According to Bada (2000: 101), 'the need for cultural literacy in English Language Teaching (ELT) arises mainly from the fact that most language learners, not exposed to cultural elements of the society in question, seem to encounter significant hardship in communicating meaning to native speakers.' Without the study of culture, teaching the target language is incomplete. Language study seems senseless to the learners of English as a foreign language (EFL) if they know nothing about the people who speak the target language or the country in which the language is spoken.

Local and national reservations sometimes prevent many learners from feeling the new language as deeply as they should. Learners should be exposed to other countries' cultural perspectives so that their preventive obstacles can be softened to welcome the new language more cordially. Overcoming the restrictions of mono-cultural views and reaching the realm of an amalgamated cultural whole can be achieved by studying another culture.

Knowledge of the codes of behavior of other people is important if a foreign language student is to communicate fully in the target language. Reviewing a broad range of cultural tips from different nationalities, this paper aims to demonstrate to foreign language teachers why and how they can incorporate the teaching of culture into their foreign language classrooms. This study addresses those countries whose foreign language centers are still monopolistically confined to one culture and it also tries to open up their narrow perspectives towards the foreign language cultures. 


\section{An Overview of Cultural Studies}

Communicative competence includes not only the linguistic knowledge but also appropriateness. It is knowledge of not only whether it is something formally possible in a language, but also the knowledge of whether it is feasible, appropriate, or done in a particular speech community (Richard et al, 2002).

The relation between language and culture has always been a concern of language two (L2) teachers and educators. Whether culture of the target language is to be incorporated into L2 teaching has been a subject of rapid change throughout language teaching history. In the course of time, there have been positive and negative views as to the inclusion of culture in language teaching programs (Sysoyev \& Donelson, 2002). The advent of Communicative Language Teaching (CLT) in the late 70s marks a critical shift for teaching culture, from form and structure to a plurality of approaches (Pulverness, 2003, in Genc \& Bada, 2005).

Recent studies focus on the indispensable relationship between L2 teaching and target culture teaching, especially over the last decade with the writings of different scholars (e.g. Byran, 1997; Byran and Morgan, 1994; Kramsch, 2001). People involved in language teaching have again begun to understand the intertwined relation between culture and language (Genc \& Bada, 2005).

The bilateral relation between language and culture has long been settled thanks to the writings of prominent philosophers (e.g., Adorno, 1993; Chomsky, 1968; Davidson, 1999; Foucault, 1994; Wittgenstein, 1999). However, the most outstanding one who dealt with the interconnection of language and culture are Sapir (1962) and Whorf (1956). They are the scholars whose names are often used synonymously with the term 'Linguistic Relativity'. Their theory suggests that we perceive the world in terms of categories and distinctions found in our native language and what is found in one language may not be found in another language due to cultural differences. According to the Sapir-Whorf hypothesis, the structure of a given language will affect the way of thinking. The implication is that people who speak different languages will think differently.

McKay (2003) believes that culture influences language teaching linguistically and pedagogically. Linguistically, it affects the semantic, pragmatic, and discourse levels of the language. Pedagogically, it influences the choice of the language materials because cultural content of the language materials and the cultural basis of the teaching methodology are to be taken into consideration while deciding upon the language materials

\subsection{Why Culture?}

The importance of teaching culture in language classes cannot be denied. Teaching culture bears some advantages:

Teaching culture helps to see the native speakers of $\mathrm{L} 2$ as real people. This can help learners associate the abstract sounds and forms of a language with real people and entities (Chastain, 1971). So studying culture helps the learners develop an authentic feel in their learning efforts.

For successful accomplishment in learning a foreign language, students need to be motivated (Gardner \& Lambert, 1972) and this motivation can be highly provided in cultural classes where the learners incorporate themselves in such activities as role-playing or storytelling. This can help the learners get rid of their unreasonable culture restrictions to see the world differently.

Besides the significant benefits of learning cultures as a means for embracing a new language, it has some side advantages, too. At least the learner can be familiar with the geography, history, customs, life styles, agriculture, and industry of the country or countries where the target language is spoken. This alone can expand the views of the learner as a human being.

\subsection{Teaching Vocabulary}

One of the most important components of language is vocabulary. When Lewis $(1993,1997)$ introduced lexical approach, perhaps his most important contribution was to highlight the importance of vocabulary in communication. It is crystal clear that when the students do not know the meaning of words, they cannot participate in the conversation successfully. What Lewis suggested was exposing the learners to words by chunks (i.e. collocation) rather than single words, but a very successful way to such exposure is through the culture-based materials where the learners can actually learn where to use the words collocationally and hence authentically based on the appropriate context. Since cultural points usually have some exquisite elements, they can attract or motivate the learners into developing the sense of using words, which will ultimately result in learning.

It is important to connect language and culture especially in teaching vocabulary. This is because some words have different connotations from culture to culture. For example, the word 'skinny' has a positive meaning for a person whose friends are overweight, but a negative connotation for an English speaker. In some cultures, having dates is 
a taboo, while in many other cultures it is something usual. So knowing the customs and the vocabulary related to the events can make language learning easier.

\subsection{Gestures}

Correct interpretation of tone of voice, facial expressions, and body language depends on cultural knowledge and such interpretations need to be practiced. The learners should be exposed to a broad range of contexts and speakers that differ in gender, social status, or nationalities. Learning a language requires behaving in an appropriate way so that it will not conflict with the norms of the target language context. Therefore, it is necessary for a language learner to see how people actually use the language. People are different all around the world and so are their gestures.

By gesture, it is meant the body and facial movement. Different cultures have developed a variety of uses for the eyes in the communication process (Smith, 1997). Americans are familiar with the admonition to maintain good eye contact with their audience. However, in some eastern and middle eastern cultures, the young people, especially girls, are taught not to look someone in the eye, especially an older one or an opposite sex because it is a sign of disrespect or violation of religious rules, while in American culture, looking at people in the audience is good, but not very good in one-to-one conversation. In lectures, British people indicate their understanding by staring at the speaker and blinking their eyes, whereas Americans nod their heads or emit some sort of sound (Gao, 2006). Iranian people, based on their educational, didactical or religious background may behave differently. Extremely religious people, for example, may avoid looking at the face of the opposite sex especially the female, while this behavior may be interpreted as an insult to other groups from the same society.

In some countries, people move their heads to convey a message. Some people shake their heads from left to right to say 'no' while this very head movement connotes 'yes' in another culture. For some people, the upward movement of the head means 'no', whereas this movement signifies 'yes' in certain cultures. In one country, using the left hand to give or take something is considered as rude or even an insult. Moving the index finger or the thumb can also be interpreted differently. Where the index finger can be used to point to something, it may have a bad interpretation in some places. The thumb may also suggest an insult if used in front of a person, while this very gesture can be freely used to wish success or call for a hitchhike in many countries.

The use of hands and arms for communicative purposes varies from culture to culture. Americans use gesture to signal activity. Among the Italians, it serves the purposes of illustration and display. The Jews use them for emphasis and the French for an expression of style and containment (Wiseman, 1993). However, not only does the use of the hands and arms can convey meanings, but their direction of movement can also be differently interpreted. When an American clasps his hands over his head, it signifies, usually with pride and occasionally a touch of arrogance, that victory over some foe has been achieved. But to the Russians this is a symbol of friendship. Thus, when Khrushchev came to the United States, decades ago, and was photographed making that gesture, millions of Americans were irritated at what they interpreted to be an arrogant signal of confidence in eventual victory of Communism over America and Capitalism. This very gesture was meant to communicate a spirit of friendship, though (Samovar, 1986).

Thus, when students come across such cultural kinetic gestures in their oral or written communications, especially in their extensive reading or even translation assignments, they may unconsciously interpret them wrongly if they have no background knowledge of the non-verbal behavior of other cultures.

\subsection{Social Behaviors}

Different cultures have different norms, values, and schemas. These differences may cause conflicts among different cultural groups. Seward (1968, in Mikiko Kawano) describes a difference about the expression of negation by citing the following situation: An American camera importer said, 'Can you ship by the end of this month?' A Japanese manufacturer answered, 'Yes, we can ship about the 20th of next month.' The manufacturer understood the question and he knew what to answer. However, his remark is inappropriate because he said 'Yes' instead of 'No'.

According to Ueda (in Prichards, 1995: 255), it is only among family members that the Japanese use 'no' without hesitation, while in public, 'exiting, lying or equivocation is preferred'. Moreover, Japanese 'Hai', which is supposed to be equivalent to English 'Yes', may mean more than 'Yes' and imply, 'I'm listening.' or 'I understand.'

Not only should lexicon and grammar be taught in language classes, but some details of the target language culture should also be provided. This can greatly help prevent misunderstanding and hence miscommunication. Even the intrinsic behaviors of the people involved may be problematic. When a teacher wants to teach a class whose 
mother tongue is different from that of the teacher, a careful investigation into the learners' idiosyncrasies can help a lot. For example, Japanese students in class frequently remain silent as a general feature of comfort in silence, a reflection of Confucianism that making mistakes is painful (Damen, 1987). If the students prefer silence and the teachers have no knowledge about the nature and personality of the learners, it could result in misinterpretation and even failure in language teaching efforts.

\subsection{Greetings}

Different cultures may have different conventions as to what is appropriate behavior in what contexts. Lack of relevant knowledge may cause intercultural misunderstanding (Hinde, 1997). In an English speaking country, where the sentence 'Where are you going' may be considered intrusive, in the Chinese culture, it is a sign of greeting which requires no true answer; just some fixed clichés such as 'Over there', 'Into town', etc. can be helpful (Oatey, 2000).

Some people shake hands when they meet each other. They may kiss their hands, their cheeks once, twice, even three times. They strike their conversation with a question about the weather, food, politics, religion, family etc. All these items can potentially be sources of problems in certain countries but quite normal and essential to many other nationalities.

In conversation, proximity is an important issue. Some cultures require closeness when two partners are talking to each other whereas in some other cultures, the farther, the better. Some people prefer long-handshakes while in some countries shaking hands is not common especially between opposite sexes.

\subsection{Linguistic Components}

Based on the properties of languages, different strategies are used in communications. In Latin-based languages, the use of abbreviations and acronyms is very common. In fact, the speakers save time and energy when they employ abbreviations and acronyms in transferring their messages. Having a good command of such elements can ease communication. When the learners become aware of such a strategy especially in oral interactions, they can easily establish successful communication.

Knowledge about the physiological ability of certain people is also useful. There are many nationalities that cannot pronounce certain sounds. They may, for example, use $/ 1 /$ in place of $/ r /$ or voiced sounds instead of voiceless sounds. This knowledge can help the speech partners anticipate what kind of interpretation to make of what they hear.

Knowledge of expressions and proverbs and their connotations will help the learners assume a better role in communication. For example in one country 'Silence is gold' while in another country, they say 'Squeaking wheels get oil.' These two contradict each other. So the learner should learn how people think and behave in other languages. Even names of certain numbers, colors, animals etc. can give rise to complications if their connotations in certain cultures are not taken into consideration. So language is not really only grammar and vocabulary.

\section{Results and Discussion}

One of the main reasons for integrating culture into the language teaching program is to raise awareness about the target language culture. As Thanasoulas (2001) points out, language teaching is culture teaching, and someone involved in teaching language is involved in teaching culture at the same time. Language does not exist in a vacuum, so language learners should be aware of the context in which the target language is used. They should also learn about the similarities and differences between their own culture and other cultures. In this way, the cultural interference which blocks learning can be prevented to a great extent and the learners can begin to understand that if they employ their own cultural norms all the time, they may cause misunderstanding.

Sometimes the learners have to sacrifice some of their norms in order to achieve some 'higher' goals. For example, if they want to learn the speaking skill, they cannot resort to silence to be efficient speakers. In this regard, Pritchard (1995) states the speed with which students are expected to respond to a question in English is shorter than that in Japanese. Students are generally to respect their teachers in the Japanese culture and it is considered impolite to respond immediately after teachers' questions. Japanese students frequently apply this 'appropriate' behavior between inferiors and superiors in an English class, but English speakers usually use time efficiently; therefore, fast speech is an asset to them; however, if the learners do not try to accommodate such a feature in their linguistic behaviors, the general atmosphere of the class will be disrupted and progress will be made on a snail-pace basis. 
People usually do not notice their own culture and consider it as the only acceptable norm, but when they come across new cultures, they may develop a sense of enmity toward them. Thus, it is necessary to be conscious of one's own culture and realize that it is one of many.

One important issue in teaching culture is what to teach. According to Brooks (1983), there are five aspects for culture: growth, refinement, fine arts, patterns of living, and a total way of life. He emphasizes the patterns of living as the most crucial one in language teaching programs. There are two types of culture; one with a capital ' $\mathrm{C}$ ' and one with a small ' $\mathrm{c}$ '. The former refers to formal culture which includes the humanistic manifestations and contributions of a foreign culture: literature, music, art, architecture, and politics. However, this way of looking at culture ignores the individual. The latter type is referred to as deep culture. This culture emphasizes people's behavioral patterns or lifestyles in eating, making friends, giving approval, or disapproval. In this way, Damen (1987) regards the knowledge of culture as the fifth skill for language learners in addition to listening, speaking, reading, and writing skills. Accordingly, she insists that culture must be taught in each language class. She also states that learners need both information about culture and exercises which demand learners' participation in order to develop intercultural awareness.

In some countries, teaching culture is not so easy, because the home teachers may not have very good command of the culture of the target language and the foreign teachers may face some difficulty in meeting the local needs. As Nicol's (2008) findings in Brunei showed, expatriate EFL teachers may bring with them a shared set of beliefs and values about how languages are best taught and learned. These teachers tend to view the local learning culture in Brunei as consisting of features that are very much the opposite of their own values, which may result in some clashes. However, they should make adjustments on the pedagogical front to accommodate the local learning culture, partly by accepting changes in conflict with their own views, and partly through negotiation with their students, having some success in persuading their students to try doing things differently.

There is, however, danger in teaching culture: lexical influence, influence on written discourse, and a drastic change in people's view of language, culture, race, ethnicity, and identity. Culture is like thin air. It is not perceived when there is no conflict, but when another culture emerges, it will be like food. There are different local and international foods. People see, smell, and taste them. There are many foods that are freely eaten, while there are some that are forbidden not only by legal and religious conventions, but also by the common sense. However, there is no danger in knowing what foods exist in the world. In fact, learning how to deal with them is important. Letting the students know how overseas people behave can facilitate the language teachers' work. They can teach cultural tips little by little according to the age and capacity of their students. If the learners are flooded with a huge bulk of cultural points, they may develop ambivalence and suspicion about the validity of their own culture. Conversely, they may despise learning the new language because of a wide range of differences or 'enmity' it may pose to their dignity. By means of a moderate integration of culture into the language programs, the teacher can let the learners be equipped to consciously anticipate any consequences commonly known as culture shock.

\section{Conclusion}

Integrating culture into the language teaching programs has a motivating effect on the language learner and the learning process. The students will be able to see similarities and differences among various cultural groups. With the globalization of life and learning, it is sometimes dangerous to be caged in a monocultural environment without any sound information about other cultures. Familiarization with other cultures leads learners to come to terms with others with a perspective of learning rather than rejecting others.

Teaching students that there are many different cultures and various ways of thinking and acting in the world, and bringing students into contact with the similarities and differences in language classes will assist the students in realizing that they should not stick only to their own norms when they communicate with foreigners in a new language. Acknowledging that there are cultural differences helps students understand that not only linguistic knowledge but also cultural information is helpful for successful communication. With this realization, it can be possible for the learners to have positive attitudes and adopt holistic approaches to language learning. A language teacher can play a very significant role in teaching culture in a language class: making the learners aware of different cultures without compromising their own identity.

\section{References}

Adorno, T. (1993). The culture industry: Selected essay on mass culture. Routledge.

Bada, E. (2000). Culture in ELT. Cukurova University Journal of Social Sciences, (6), 100-110.

Brooks, N. (1983). Teaching Culture in the Foreign Language Classroom. Foreign Language Annals, 16. New York: ACTFL, Inc. 
Byran M. (1997). Cultural studies and foreign language teaching. In Bassnett, S. (Ed.), Studying British Cultures: An Introduction (pp. 53-65). London: Routledge.

Byran, M., \& Morgan, C. (1994). Teaching-and-learning language-and-culture. Clevedon: Multilingual Matters Ltd.

Chastain, K. (1971). The development of modern language skills: Theory to practice. Chicago: Rand McNally.

Chomsky, N. (1968). Language and mind. Harcourt Brace Jovanovich, Inc.

Damen, L. (1987). Culture learning: The fifth dimension in the language classroom. Addison-Wesley Publisher Company.

Davidson, D. (1999). The philosophy of Donald Davidson. (Ed) Lewis Edwin Hahn. Illinois: Open Court Publishing Company.

Foucault, M. (1994). The order of things: An archaeology of the human sciences. USA: Vintage Books.

Gao, F. (2006). Language Is Culture: On Intercultural Communication. Journal of Language and Linguistics, 5(1). Retrieved from http://www.jllonline.co.uk/journal/5_1/gao.htm

Gardner, R. C., \& Lambert, W. E. (1972). Attitudes and motivation in second language learning. Rowley, Mass.: Newbury House.

Genc, B., Bada, E. (2005, April). Culture in Language Learning and Teaching. The Reading Matrix, 5(1). Retrieved from http://www.readingmatrix.com/articles/genc_bada/article.pdf

Hinde, R.A. (1997). Non-verbal communication. Cambridge University Press.

Kramsch, C. (2001). Language and culture. Oxford: Oxford University Press.

Lewis M. (1997). Implementing the lexical approach. putting theory into practice. Australia: Thomson Heinle.

Lewis, M. (1993). The lexical approach: The state of ELT and a way forward. Hove, UK: Language Teaching Publications.

McKay, S. L. (2003). The Cultural Basis of Teaching English as an International Language. TESOL Matters, 13(4), September /October / November.

Mikiko Kawano. (n.d.). Minor project: Teaching cultures in English class in Japan. Retrieved from http://www.cdu.edu.au/ehs/kawano/Teachingculture.pdf

Nicol, M. F. (2008). A Clash of Learning Cultures? Expatriate TEFL Teachers in Brunei Darussalam. 3L: Language, Linguistics, $\quad$ Literature, $14 . \quad$ Retrieved from http://www.ukm.my/ppbl/3L/Full\%20text\%20pdf/3LVol14/1-Mary\%20F\%20Nicol.pdf

Oatey, H. S. (2000). Culturally speaking: Managing rapport through talk across culture. London: Continuum.

Prichards, R.M.O. (1995). Amae and Japanese Learner. Language, Culture and Curriculum, 8(3), 249-264.

Richards, et al. (2002). Dictionary of language teaching \& applied linguistics. Essex: Longman.

Samovar, L. A. (1986). Intercultural communication: A reader. U.S: Wadsworth Publishing Company.

Smith, E. L. (1997). Discourse across cultures: Strategies in world Englishes. U.S: Pentice Hall.

Sysoyev, P. V., \& Donelson L. R. (2002). Teaching Cultural Identity Through Modern Language: Discourse as a Marker of an Individual's Cultural Identity. Journal of Euroasian Research. Retrieved from http://www.americancouncils.org/JER/archive2/issue4/11.htm

Thanasoulas, D. (2001). The Importance of Teaching Culture in Foreign Language Classroom. Radical Pedagogy. Retrieved from http://radicalpedagogy.icaap.org/content/issue3_3/7-thanasoulas.html

Wiseman, L.R. (1993). Intercultural communication competence. International Education and Professional Publisher.

Wittgenstein, L (1999). Philosophical investigations, trans. by. G. E. M. Anscombe. Prentice Hall. 